\title{
Quantitative determination of caffeine in different matrices
}

\author{
Nevena Grujić-Letić ${ }^{1}$, Branislava Rakić ${ }^{1,2^{*}}$, Emilia Šefer ${ }^{1}$, Maja Milanović ${ }^{1}$, Maja \\ Nikšić ${ }^{1}$ Ivana Vujić ${ }^{1}$, Nataša Milić ${ }^{1}$ \\ ${ }^{1}$ University of Novi Sad, Faculty of Medicine, 21000 Novi Sad, Serbia \\ ${ }^{2}$ University business academy in Novi Sad, Faculty of Pharmacy, Novi Sad, Serbia
}

Received: September 2016; Accepted: October 2016

\begin{abstract}
Caffeine is odorless, bitter taste substance which can be naturally found in coffee, cocoa, tea leaves, and is intentionally added in food and pharmaceutical products. It can also be found in surface water in small concentrations where is often used as an excellent indicator of human waste. The aim of the work is determination of caffeine content in food, beverages, analgesics and surface water using solidphase extraction followed by high-performance liquid chromatography (HPLC). Caffeine content was determined in 12 commercial tea and coffee products, non-alcoholic energy drinks and food, 5 combined preparations of analgesics and the Danube samples collected from 7 representative locations. The results showed that caffeine content in food ranged 5,6-158 mg/100 g, tea samples 24,71-30,81 mg/100 ml, coffee samples 1328-3594 mg/100 g, energy drinks 9,69-30,79 mg/100 ml and in the Danube samples 15,91-306,12 ng/l. Caffeine content in combined commercial formulations of non-narcotic analgesics of all brands did meet specifications. The data suggested that the proposed HPLC method can be used for routine determination and control of caffeine content in different matrices.
\end{abstract}

Keywords: analgesics; caffeine; food; HPLC; surface water

\section{Introduction}

Caffeine is an odorless and slightly bitter methylxanthine derivative that can be naturally found in the coffee and cocoa beans, tea leaves and other plant species (Amare and Admassie, 2012; Castro et al., 2010). It can be consumed in the form of coffee, tea, cocoa, chocolate and popular carbonated energy drinks where is intentionally added. Moreover, it is considered to be one of the most commonly consumed drug with more than 80 percent of the world's population consuming caffeine daily (Carrillo and Benitez, 2000; Norton et al., 2011). The Europeans are found to be the world's largest consumers of caffeine intake of approximately $4.6 \mathrm{~kg} /$ person/year. Caffeine is quickly absorbed by the body. The human salivary level, which indicates the extent of absorption, peaks around 40 minutes after caf- feine consumption (Chou and Bell, 2007). This pharmacologically active substance stimulates the central nervous system, increases heartbeat rate, dilates blood vessels and works as a weak diuretic. However, the high amounts of caffeine can cause trembling, nausea, nervousness and seizure. A fatal dose of caffeine has been evaluated to be more than $10 \mathrm{~g}$ (about $170 \mathrm{mg} / \mathrm{kg}$ of body weight). It is also considered to be a risk species for cardiovascular diseases, kidney malfunction, asthma, and may also cause hyperactivity (Abebe et al., 2008; Carvalho et al., 2012; Evans and Griffiths, 1992).

Other important usage of caffeine is as an analgesic adjuvant in drug formulations for the treatment of headache and pain related to postpartum, postoperative, and dental surgery and it is therapeutically applied for the treatment of migraine in combination with other drugs such as aspirin, paracetamol and tramadol. According to literature, adding

\footnotetext{
*rakic.branislava@gmail.com
} 
caffeine to pain analgesics can make pain pills work $40 \%$ more effectively. This added boost to medications pain-relieving ability allows you to take less medication and reduce the risk of becoming the addicted to the pharmaceutical preparation especially if it contains opioid component. Caffeine also eliminates possible sedative effects that can be evoked by various analgesics. Together with its light mood-elevating effects, it contributes to the completeness of the desired therapeutic effect for patients (Madhusudhan, 2013; Straube et al., 2011). However, a person taking combined drugs containing caffeine are more likely to experience adverse effects like tachycardia, anxiety and ectopic beats (Sawynok, 2011).

The presence of the pharmaceutical residues in the environment has become the subject of growing concern in the past decade. Due to the continuous input that leads to the long-term adverse effects on the aquatic and terrestrial organisms, the special attention is being paid to their concentration levels in the aquatic environment. Pharmaceuticals are poorly degradable and can pass through all the natural filtrations and reach ground water and ultimately drinking water. Caffeine can be found in traces in surface water. The main paths for caffeine to enter wastewater stream are either in urine or when caffeine-containing products are discharged through household pipelines or sewers (Seiler et al., 1999). Determination of caffeine in surface water is an important task for environmental researches and analysis because it is found to be a good indicator for human sewage because of its relatively high concentrations in surface water and its unambiguous anthropogenic origin (Grujić Letić et al., 2015).

The most popular techniques for caffeine determination in different mixtures include HPLC, UV/Vis spectroscopy, thin-layer chromatography, ion chromatography, etc (Boshenska, 2013). All of the HPLC methods mainly used C18 columns to determine caffeine content (Alvi and Hammami, 2011; Coco et al., 2007; Tzanavaras and Themelis, 2007). Also, there is no known unique method developed for caffeine determination from different matrices.

Accordingly, the goals of this study were to develope and validate a matrix-specified HPLC method for caffeine determination in food, beverages, surface water and pharmaceuticals which is simple and easy to perform. This method could have a widespread application in food, environmental and pharmaceutical sciences.

\section{Materials and methods}

\section{Chemicals}

The standard of caffeine ( $99 \%$ purity), acetonitrile and methanol were obtained from Sigma (Deisenhofen, Germany). Chloroform and tetrahydrofurane (THF) were purchased from Mallinckrodt Baker Inc. (Phillipsburg, NJ, USA). Ultra pure water was used for the preparation of all solutions (Milli-Q-quality).
All solvents and reagents were of an analytical grade unless indicated otherwise.

\section{Instrumentation and operating conditions}

Determination of caffeine was performed by HPLC. The chromatography was using two-solvent isocratic elution. The HPLC-diode array detection (DAD) model Agilent HP 1100 system equipped with an autosampler (Waldbronn, Germany) was used. The analytical column was the Zorbax Eclipse XDB-C8 column (4.6 mm x 150 $\mathrm{mm}$, i.d., $5 \mu \mathrm{m}$ particle size). Mobile phase was waterTHF $(0.1 \%$ THF in water adjusted to $\mathrm{pH} 8$ with $0.1 \mathrm{M}$ $\mathrm{NaOH})$ - acetonitrile (90:10) with a flow rate of $0.8 \mathrm{~mL} /$ $\mathrm{min}$. The HPLC mobile phase was prepared fresh daily and filtered through a $0.45 \mu \mathrm{m}$ nylon filter. Run time was 10 min, column temperature $25^{\circ} \mathrm{C}$ and analytes were detected at $273 \mathrm{~nm}$.

The Supelclean ${ }^{\mathrm{TM}}$ LC-18 SPE cartridges $6 \mathrm{~mL}(0.5$ g) used for solid phase extraction were obtained from Supelco, USA. The SPE was performed in a 12-position Vacuum Manifold, Supelco, USA.

\section{Preparation of stock and working standard solutions and calibration}

The standard stock solution of caffeine was prepared by dissolving $10 \mathrm{mg}$ of the standard substance in $10 \mathrm{~mL}$ of water $\mathrm{pH}$ 8. The solution was stable approximately three days under refrigeration $\left(4^{\circ} \mathrm{C}\right)$.

Working solutions were prepared by diluting $100 \mu \mathrm{l}$ of the stock solution to $1 \mathrm{~mL}$ with water $\mathrm{pH} 8$ to obtain concentration $0.1 \mathrm{mg} / \mathrm{mL}$. (0.2-10) $\mu \mathrm{L}$ of working solutions were injected into the HPLC system and the peak area responses were obtained (Fig. 1). A method of the external standard calibration was used. Linear standard curve for caffeine was determined by plotting masses versus area responses and each calibration point was obtained as an average of three injections.

\section{Sample preparation and cleanup procedure}

Samples for caffeine determination in food and beverages were purchased at the Serbian market. Natural products Black tea, Mate tea, Green tea, White tea, Barcaffe Classic, Nescaffe Classic and Cocoa powder were obtained from Macval Tea D.O.O. (Novi Sad, Serbia), Nestle (Belgrade, Serbia) and Aleva (Novi Knezevac, Serbia). Coca Cola, Red Bull and Pepsi were purchased from Coca Cola HBC (Belgrade, Serbia) and Max Co. (Novi Sad, Serbia). Baking and Milka chocolates were obtained from Max Co. (Novi Sad, Serbia). The water extracts of teas were prepared by boiling $5 \mathrm{~g}$ with $200 \mathrm{~mL}$ of water for 30 minutes. The extracts were filtered and adjusted with water $\mathrm{pH} 8$ to $10 \mathrm{~mL}$ and then subjested to the clean-up procedure described later. Coffee samples ( $5 \mathrm{~g}$ ) were extraced with 200 

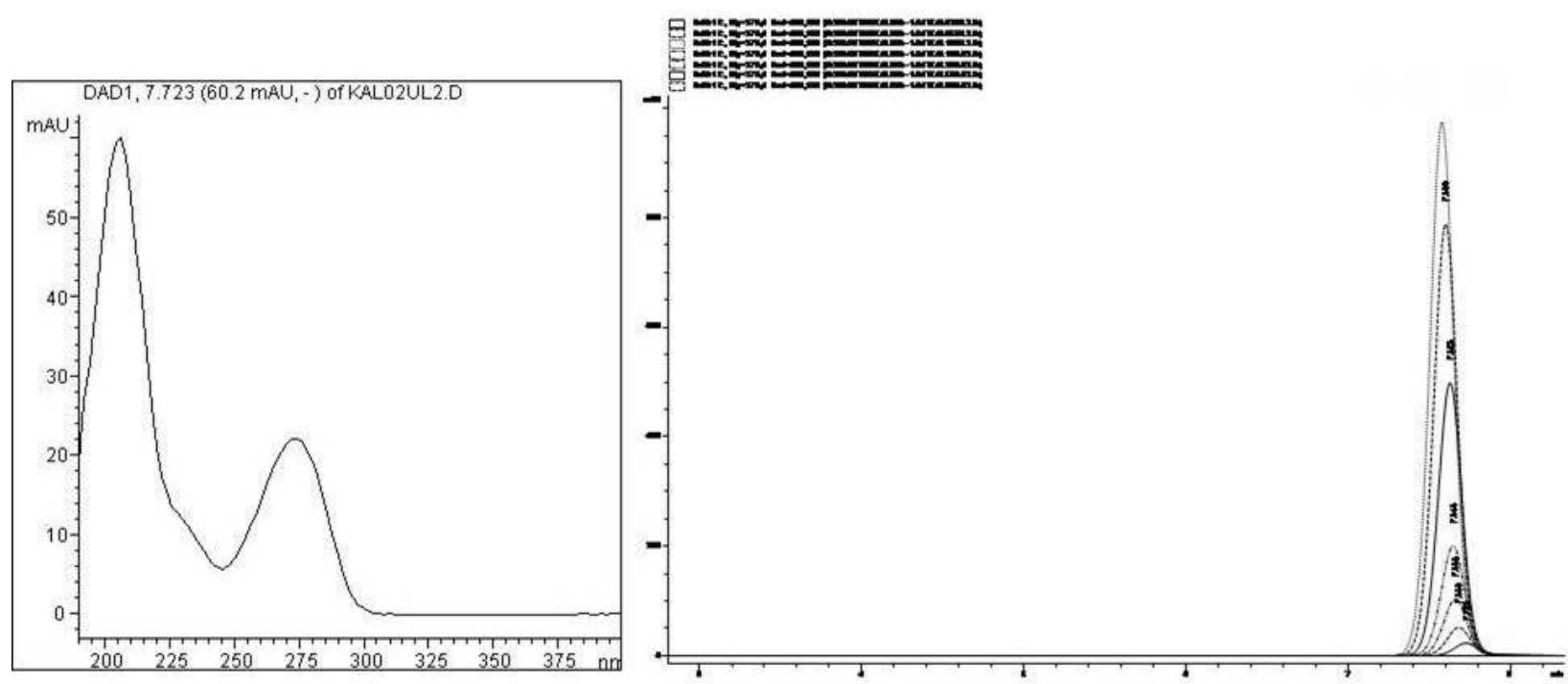

Fig. 1. a) UV spectrum of caffeine; b) HPLC chromatograms of working standard solutions of caffeine

$\mathrm{mL}$ of boiling water for 5 minutes and filtered. The cocoa powder $(5 \mathrm{~g})$, baking chocolate $(8.85 \mathrm{~g})$ and Milka chocolate $(8.22 \mathrm{~g})$ were filled up to $200 \mathrm{~mL}$ of water and extraced for 30 minutes at $60{ }^{\circ} \mathrm{C}$ in ultrasonic bath. The extracts were filtered. The samples of fizzy drinks were degassed for 15 minutes in ultrasonic bath to remove $\mathrm{CO}_{2}$. Prior the clean-up procedure and analysis, extracts were filtered through $0.22-\mu \mathrm{m}$ nylon filters (Srdjenovic et al., 2008).

Samples for caffeine determination in surface water were collected in amber bottles from seven representative locations of the Danube River on the teritory of Novi $\mathrm{Sad}$, Serbia, and stored at $4{ }^{\circ} \mathrm{C}$ until analysis. Samples were collected in summer, fall, winter and spring under comparable meteorological conditions at all sites for each sampling. The water samples were taken in the middle of the river and along the coast below the water surface (3 samples) and 100 meters downstream of the each sewage discharge (4 samples). All samples were filtered through a $0.45-\mu \mathrm{m}$ Nylon membrane filter prior extraction (GrujićLetić et al., 2015).

Tablets of analgoantipyretics containing caffeine were purchased from pharmacies in the vicinity of Novi Sad, Serbia. Twenty tablets from each brand were randomly selected and weight individually using the electronic weighing balance. The weight (mean \pm standard deviation) was calculated. The tablets were pulverized and average mass of one tablet was weight and transferred to laboratory flask. $50 \mathrm{~mL}$ of water $\mathrm{pH} 8$ was added and heated to the boiling point. The samples were filtered directly in a separatory funnel and extracted with $2 \times 10 \mathrm{~mL}$ of chloroform. Chloroform solution was collected in a $125 \mathrm{~mL}$ Erlenmeyer flask and anhydrous sodium sulfate was added to the solution until it stopped clumping. The dried solution was decanted in a round-bottom flask and evaporated to dryness un- der nitrogen. The residue of all samples was reconstituted in $2 \mathrm{~mL}$ of water $\mathrm{pH} 8$.

The Supelclean ${ }^{\mathrm{TM}}$ LC-18 SPE cartridges were conditioned with $2 \times 6 \mathrm{~mL}$ of chloroform, dichloromethane, methanol and HPLC grade water. $10 \mathrm{~mL}$ of beverages and food filtrates and $3 \mathrm{~L}$ of the Danube River samples were passed through the SPE cartridges and the elutes were rejected. Caffeine was eluted from the SPE cartridges with $2 \times 10 \mathrm{~mL}$ of chloroform into an evaporating flask. The solution was evaporated to dryness under nitrogen. The residue of all samples was reconstituted in $2 \mathrm{~mL}$ of water $\mathrm{pH}$ 8. Prior to the analysis, the samples were filtered through a $0.45 \mu \mathrm{m}$ nylon filter and injected into HPLC system (Srdjenovic et al., 2008).

\section{Statistical analysis}

The statistical analyses were performed by MS Excel ${ }^{\circledR}$ 2013 software. Comparison of mean values of measured parameters was performed by a one-way ANOVA (SPSS, version 17).

\section{Results and discussion}

\section{Determination of caffeine in food and beverages}

The Food and Drug Administration (FDA) has included caffeine in the list of substances that are generally recognized as safe (Chou and Bell, 2007). Experimental data for caffeine analysis in food and beverages are presented in Table 1 and Figure 2. The results showed that caffeine content in food ranged $5,6-158 \mathrm{mg} / 100 \mathrm{~g}$, tea samples 24,71-30,81 mg/100 ml, coffee samples 1328$3594 \mathrm{mg} / 100 \mathrm{~g}$ and energy drinks $9,69-30,79 \mathrm{mg} / 100 \mathrm{ml}$. 
Table 1. Determination of caffeine content in beverages and food

\begin{tabular}{ccccc}
\hline \hline \multicolumn{5}{c}{ Caffeine amount $(\mathrm{mg} / 100 \mathrm{~mL})$} \\
\hline Sample No. & Sample & Retention time $(\mathrm{min})$ & Determined value & Declared value \\
1 & Coca Cola & 7.599 & $9.69 \pm 0.221$ & $<15$ \\
2 & Red Bull & 7.584 & $30.79 \pm 0.112$ & $<32$ \\
3 & Pepsi & 7.613 & $11.91 \pm 0.099$ & $<15$ \\
& & Caffeine amount $(\mathrm{mg} / 100 \mathrm{~g})$ & & - \\
4 & Black tea & 7.826 & $1263.15 \pm 0.455$ & - \\
5 & Green tea & 7.856 & $1013.00 \pm 0.621$ & - \\
6 & Mate tea & 7.919 & $1116.7 \pm 0.770$ & - \\
7 & White tea & 7.822 & $980.52 \pm 0.821$ & $<2000$ \\
8 & Barcaffe Classic & 7.600 & $1328.54 \pm 0.558$ & - \\
9 & Nescaffe Classic & 7.617 & $3594.71 \pm 0.772$ & - \\
10 & Cocoa & 7.605 & $48.91 \pm 0.336$ & - \\
11 & Baking chocolade & 7.622 & $158.00 \pm 0.500$ & - \\
12 & Milka chocolade & 7.599 & $5.66 \pm 0.091$ & \\
\hline
\end{tabular}

Data are expressed as the averages \pm standard deviations of triplicate measurements

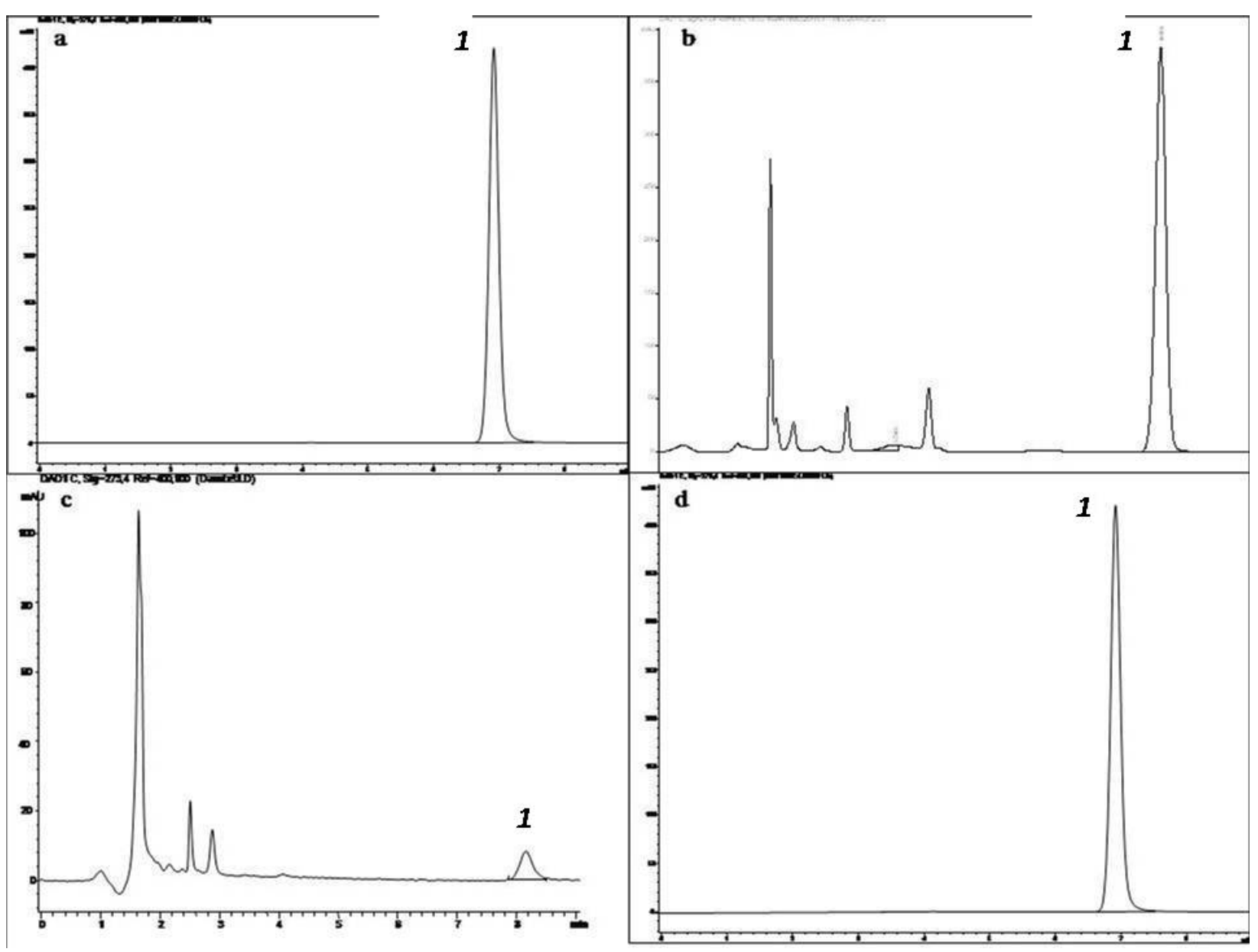

Fig. 2. Representative chromatograms of real samples containing caffeine (1): a) Mate tea; b) Cocoa; c) Danube sample (Ratno ostrvo); d) Combined analgesic tablet $\left(\right.$ Caffetin $\left.^{\circledR}\right)$ 
Highest amount among teas was determined in black tea and the lowest in white tea which is in an agreement with the literature (Chin et al., 2008). Energy drinks have become quite popular among adolescents and young adults. Results from the Monitoring the Future study found that among 22,000 U.S. secondary school students surveyed, $30 \%$ reported using energetic drinks. The consumption frequency is concerning due to serious side effects associated with caffeine intake such as heart palpitations, hypertension, nausea and vomiting and in some rare cases even death (Sather et al., 2016; Terry-McElrath, et al., 2014). Of the carbonated sodas evaluated in this work, the highest caffeine concentration was found in Red Bull. In tested food samples baking chocolate had the highest caffeine amount $(158 \mathrm{mg} / 100 \mathrm{~g})$. The obtained values in this study were consistent with the available manufacturer data.

FDA set the maximum concentration of caffeine only in cola beverages at $32.4 \mathrm{mg}$ of caffeine per $6-\mathrm{oz}$ bottle or $200 \mathrm{mg} / \mathrm{L}$, but not in energy drinks and coffee beverages. Because of the health concerns connected with caffeine intake, all caffeinated beverages and food should be carefully used and include appropriate warning labels. Without caffeine value set on the label, consumers are left relatively uninformed regarding its amount in these beverages (Chou and Bell, 2007). Therefore, it is important to monitor caffeine content in beverages and food by establishing a more precise, simple, rapid and low cost analytical method in order to study its physiological effects on the human body's metabolism, including stimulating the central nervous system and increasing blood pressure in the short term and food quality (Rostagno et al., 2011; Sereshti and Samadi, 2014).

\section{Determination of caffeine in the Danube River samples}

Table 2 summarizes seasonal variations in caffeine concentrations in seven selected sites along the Danube River. Representative chromatogram of real sample (Ratno ostrvo) is shown on Figure 2. Obtained results confirmed a presence of this emerging substance in four samples taken near wastewater discharges and followed the prediction that caffeine would be present in areas of human impact. The highest caffeine concentrations were found at the site "Beogradski kej" and the lowest (under the limit of detection) were found in the middle and on the left and right side of the Danube River, the sites furthest from direct human impact. Mean caffeine concentrations for summer, fall, winter and spring periods were $24.78 \mathrm{ng} / \mathrm{L}, 26.83 \mathrm{ng} / \mathrm{L}, 24.61$ $\mathrm{ng} / \mathrm{L}$, and $86.29 \mathrm{ng} / \mathrm{L}$, respectively. The highest mean caffeine concentration was detected in samples collected in the spring period. This seasonal difference could be the result of variations in environmental conditions such as rainfall and temperature or different seasonal caffeine intake. There was no significant difference between mean caffeine concentrations determined for summer, fall and winter period in our study. Obtained results are in an agreement with the study performed in the Spain where highest values were determined in samples collected in the spring period (Fernandez et al., 2010). Highest mean caffeine concentration in our research $(86.29 \mathrm{ng} / \mathrm{L})$ is lower than one obtained in recent publication analyzing Danube River samples for this pharmaceutically active substance (137 ng/L) (Loos et al., 2010). Evaluation of potential risk for aquatic organisms in our research showed that it belonged to Class II (sublethal effects on the aquatic organisms) (Grujić Letić et al., 2015). This indicates that potential risk for chronic effects may occur in resident organisms in the long-term period and that appropriate treatment of wastewater would be essential in prevention of the potential pollution.

\section{Determination of caffeine in the combined commercial formulations of non-narcotic analgoantipiretics}

As per published literature, adding caffeine to pain analgesics such as paracetamol and tramadol can make

Table 2. Seasonal monitoring of caffeine concentrations in the Danube samples

\begin{tabular}{|c|c|c|c|c|c|c|}
\hline \multicolumn{7}{|c|}{ Caffeine amount (ng/L) } \\
\hline Sampling site & Norten latitude & $\begin{array}{l}\text { Eastern longi- } \\
\text { tude }\end{array}$ & Spring & Winter & Summer & Autumn \\
\hline Cepelin & $45^{\circ} 15^{\prime} 5,42^{\prime \prime} \mathrm{N}$ & $19^{\circ} 51^{\prime} 22,95^{\prime \prime} \mathrm{E}$ & $306.12 \pm 0.082$ & $42.80 \pm 0.011$ & $27.78 \pm 0.009$ & $39.90 \pm 0.006$ \\
\hline Beogradski kej & $45^{\circ} 15^{\prime} 44,4^{\prime \prime} \mathrm{N}$ & $19^{\circ} 51^{\prime} 28,46^{\prime \prime} \mathrm{E}$ & $228.01 \pm 0.045$ & $81.70 \pm 0.028$ & $37.40 \pm 0.001$ & $84.24 \pm 0.033$ \\
\hline Rokov potok & $45^{\circ} 15^{\prime} 2,2^{\prime \prime} \mathrm{N}$ & $19^{\circ} 54^{\prime} 9,92^{\prime \prime} \mathrm{E}$ & $31.11 \pm 0.023$ & $15.91 \pm 0.009$ & $84.05 \pm 0.030$ & $28.84 \pm 0.009$ \\
\hline Ratno ostrvo & $45^{\circ} 15^{\prime} 11,84^{\prime \prime} \mathrm{N}$ & $19^{\circ} 54^{\prime} 40,18^{\prime \prime} \mathrm{E}$ & $39.20 \pm 0.011$ & $31.93 \pm 0.013$ & $24.28 \pm 0.007$ & $34.88 \pm 0.007$ \\
\hline Danube middle & $45^{\circ} 14^{\prime} 34,91 ’ \mathrm{~N}$ & $19^{\circ} 54^{\prime} 55,53^{\prime \prime} \mathrm{E}$ & n.d. & n.d. & n.d. & n.d. \\
\hline Danube left & $45^{\circ} 14^{\prime} 33,24 ’ \mathrm{~N}$ & $19^{\circ} 55^{\prime} 5,08^{\prime \prime} \mathrm{E}$ & n.d. & n.d. & n.d. & n.d. \\
\hline Danube right & $45^{\circ} 14^{\prime} 30,61 ’ \mathrm{~N}$ & $19^{\circ} 54^{\prime} 48,52^{\prime \prime} \mathrm{E}$ & n.d. & n.d. & n.d. & n.d. \\
\hline
\end{tabular}

Data are expressed as the averages \pm standard deviations of triplicate measurements n.d., not detected 
Table 3. Determination of caffeine content in combined commercial formulations of non-narcotic analgoantipiretics

\begin{tabular}{ccccccc}
\hline \hline $\begin{array}{c}\text { Sample } \\
\text { No. }\end{array}$ & Brand name & Expiry date & Serial No. & Weight (mg) & $\begin{array}{c}\text { Determined caffeine } \\
\text { amount (mg) }\end{array}$ & $\begin{array}{c}\text { Declared caffeine } \\
\text { amount (mg) }\end{array}$ \\
\hline 1 & Panadol Extra & $03-2017$ & FF7L & $760.00 \pm 0.88$ & $64.28 \pm 0.500$ & 65 \\
2 & Kofan Instant & $02-2020$ & 93330216 & $560.00 \pm 0.33$ & $48.22 \pm 0.771$ & 50 \\
3 & Oldon & $04-2017$ & 56221525 & $636.60 \pm 0.28$ & $48.90 \pm 0.892$ & 50 \\
4 & Caffebol & $01-2018$ & M500256 & $628.80 \pm 0.55$ & $50.37 \pm 0.333$ & 50 \\
5 & Caffetin & $06-2017$ & 738560614 & $631.70 \pm 0.10$ & $48.88 \pm 0.454$ & 50 \\
\hline
\end{tabular}

Data are expressed as the averages \pm standard deviations of triplicate measurements

pills work more effectively. Also, caffeine has been found to accentuate the analgesic effects of acetaminophen and acetyl salicylic acid in a broad collection of pain states such as dysmenorrhoea, cancer pain, post-partum pain, sore throat and dental post-surgery pain. Caffeine mitigates the protein synthesis of COX-2. In this way it enhances analgesia in combination with paracetamol. Studies showed that caffeine accelerated acetaminophen absorption which resulted in its enhanced and prolonged analgesic activity. Some clinical studies were performed to evaluate caffeine as an analgesic adjuvant from patients with postpartum uterine cramping or episiotomy pain, headache, backache and abdominal cramping. These studies showed that to obtain the same amount of response, approximately $40 \%$ higher dose of analgesic without caffeine was requested than one with caffeine (Madhusudhan, 2013; Renner et al., 2007).

The results of the assay of chemical content using HPLC analysis to determine the amount of caffeine present in each brand of combined analgesics in this work are shown in Table 3 and Figure 2. All the brands met compendia requirements with regards to uniformity of weight. The caffeine content varied from (96.48-100.74) $\%$ of the declared value. The requirements of the British Pharmacopoeia (2011) include (95-105) \% of active drug content. According to obtained data it can be concluded that all brands did meet this specification in the HPLC assay method.

The results of this study indicated that proposed HPLC method could be used for routine determination and quality control of caffeine content in combined tablets of analgesics.

\section{Conclusion}

The results of food and beverages analysis showed that caffeine content was consistent with the available manufacturer data and obtained data for combined commercial formulations of non-narcotic analgesics of all brands did meet specification of the British Pharmacopoeia for active drug content.

Testing the surface water samples for caffeine showed that significant concentrations were found at the sampling sites near the wastewater discharges. Calculating the potential risk for aquatic organisms in our research showed that potential risk for chronic effects may occur in resident organisms in the long-term period and appropriate treatment of wastewater would be essential in prevention of the potential pollution. Knowing that there is black box in methodology as well as in the legislation of emerging contaminants for surface water and that the quality of surface water is of great importance for risk management and health and safety environment, this work could have a widespread application in environmental sciences.

\section{Acknowledgment}

The work was financially supported by Ministry of Education and Science, Republic of Serbia (III46009) and NATO Science for Peace Project "Drinking Water Quality Risk Assessment and Prevention in Novi Sad municipality, Serbia" (ESP.EAP.SFP 984087).

\section{References}

Amare, M., Shimelis, A., 2012. Polymer Modified Glassy Carbon Electrode for the Electrochemical Determination of Caffeine in Coffee. Talanta 93, 122-128. doi:10.1016/j. talanta.2012.01.058.

Belay, A., Kassahun, T., Mesfin , R., Araya A., 2008. Measurement of Caffeine in Coffee Beans with UV/vis Spectrometer. Food Chemistry 108(1), 310-315. doi:10.1016/j. foodchem.2007.10.024.

British pharmacopoaeia. Vol. I. 2011. London, UK: British Pharmacopoeia Commission.

Carrillo, J, Benitez, J., 2000. Clinically Significant Pharmacokinetic Interactions between Dietary Caffeine and Medications. Clinical Pharmacokinetics 39(2), 127-153. doi:10.2165/00003088-200039020-00004.

Castro, J., Pregibon T., Chumanov K., Kenneth RM.,. 2010. Determination of catechins and caffeine in proposed green tea standard reference materials by liquid chromatographyparticle beam/electron ionization mass spectrometry (LCPB/EIMS). Talanta 82, 1687-1695.

Chin, J.M., Merves M.L., Goldberger B., Sampson-Cone A., Cone E.J., 2008. Caffeine Content of Brewed Teas. Journal 
of Analytical Toxicology 32(8), 702-704. doi:10.1093/ jat/32.8.702.

Chou, K.H., Bell L.N., 2007. Caffeine Content of Prepackaged National-Brand and Private-Label Carbonated Beverages. Journal of Food Science 72(6), C337-342. doi:10.1111/ j.1750-3841.2007.00414.x.

Coco, F., Lanuzza L.F., Micali G., and Cappellano G., 2007. Determination of Theobromine, Theophylline, and Caffeine in by-Products of Cupuacu and Cacao Seeds by High-Performance Liquid Chromatography. Journal of Chromatographic Science 45(5), 273-275. doi:10.1093/ chromsci/45.5.273.

Evans, S.M., Griffiths R.R., 1992. Caffeine Tolerance and Choice in Humans. Psychopharmacology 108(1-2), 51-59. doi:10.1007/BF02245285.

Fernandez, C., Gonzalez-Doncel M., Pro J., Carbonell G., Tarazona J.V., 2010. Occurrence of Pharmaceutically Active Compounds in Surface Waters of the Henares-JaramaTajo River System (madrid, Spain) and a Potential Risk Characterization. Science of the Total Environment 408(3), 543-551. doi:10.1016/j.scitotenv.2009.10.009.

Grujić Letić, N., Milanović M., Milić N., Vojinović Miloradov M., Radonić J., Mihajlović I., Turk Sekulić M., 2015. Determination of emerging substances in the Danube and potential risk evaluation. CLEAN - Soil, Air, Water 43, 731738.

Loos, R., Locoro G., Comero S, Contini S., Schwesig D., Werres F., Balsaa P., Gans, O., Weiss, S., Blaha, L., Bolchi, M., Gawlik, B.M., 2010. Pan-European Survey on the Occurrence of Selected Polar Organic Persistent Pollutants in Ground Water. Water Research 44(14), 4115-4126. doi:10.1016/j.watres.2010.05.032.

Madhusudhan, S.K., 2013. Novel analgesic combination of tramadol, paracetamol, caffeine and taurine in the management of moderate to moderately severeacute low back pain. Journal of Orthopaedics 10, 144-148.

Norton, T.R., Lazev, A.B., Sullivan, M.J., 2011. The 'Buzz' on Caffeine: Patterns of Caffeine Use in a Convenience Sample of College Students. Journal of Caffeine Research 1(1), 3540. doi:10.1089/jer.2010.0003.

Bertold R., Clarke, G., Grattan, T., Beisel, A., Mueller C., Werner, U., Kobal, G., Brune, K., 2007. Caffeine Accelerates Absorption and Enhances the Analgesic Effect of Acetaminophen. Journal of Clinical Pharmacology 47(6), 715-726. doi:10.1177/0091270007299762.
Rostagno, M.A., Manchon, N., D’Arrigo, M., Guillam E., Villares A., Garcia-Lafuente, A. Ramos, A., Martinez J.A., 2011. Fast and Simultaneous Determination of Phenolic Compounds and Caffeine in Teas, Mate, Instant Coffee, Soft Drink and Energetic Drink by High-Performance Liquid Chromatography Using a Fused-Core Column. Analytica Chimica Acta 685(2), 204-211. doi:10.1016/j. aca.2010.11.031

Sather, T.E., Woolsey, C.L., Williams, R.D., Evans, M.W., Cromartie, F., 2016. Age of First Use of Energy Beverages Predicts Future Maximal Consumption among Naval Pilot and Flight Officer Candidates. Addictive Behaviors Reports 3, 9-13. doi:10.1016/j.abrep.2015.12.001.

Sawynok, J., 2011. Caffeine and Pain. Pain 152, 726-729. doi:10.1016/j.pain.2010.10.011.

Seiler, R.L., Zaugg, S.D, Thomas J.M, Howcrof D.L. 1999. Caffeine and Pharmaceuticals as Indicators of Waste Water Contamination in Wells. Groundwater 37(3), 405-410. doi:10.1111/j.1745-6584.1999.tb01118.x.

Sereshti, H., and Soheila S., 2014. A Rapid and Simple Determination of Caffeine in Teas, Coffees and Eight Beverages. Food Chemistry 158, 8-13. doi:10.1016/j. foodchem.2014.02.095.

Srdjenovic, B., Djordjevic-Milic V., Grujic N., Injac R., Lepojevic Z., 2008. Simultaneous HPLC Determination of Caffeine, Theobromine, and Theophylline in Food, Drinks, and Herbal Products. Journal of Chromatographic Science 46(February), 144-149. doi:10.1093/chromsci/46.2.144.

Straube, A., Aicher, B., Fiebich, B.L, Haag, G., 2011. Combined Analgesics in (headache) Pain Therapy: Shotgun Approach or Precise Multi-Target Therapeutics? BMC Neurology 11(1), 43. doi:10.1186/1471-2377-11-43.

Terry-McElrath, Y.M., O’Malley, P.M., Johnston, L.D., 2014. Energy Drinks, Soft Drinks, and Substance Use among United States Secondary School Students. Journal of Addiction Medicine 8(1), 6-13. doi:10.1097/01. ADM.0000435322.07020.53.

Tzanavaras, P.D., Themelis, D.G., 2007. Development and Validation of a High-Throughput High-Performance Liquid Chromatographic Assay for the Determination of Caffeine in Food Samples Using a Monolithic Column. Analytica Chimica Acta 581(1), 89-94. doi:10.1016/j.aca.2006.07.081. 
Резиме

\title{
Квантитативно определеување на кофеин во различни матрици
}

\author{
Невена Грујиќ-Летиќ ${ }^{1}$, Бранислава Ракиќ ${ }^{1,2 *}$, Емилија Шефер ${ }^{1}$, Маја Милановиќ ${ }^{1}$, \\ Маја Никшиќ ${ }^{1}$, Ивана Вујиќ ${ }^{1}$, Наташа Милиќ ${ }^{1}$ \\ ${ }^{1}$ Универзийет̄ оя Нови Сая, Меоицински Факулитет̄, 21000 Нови Сая, Србија \\ ${ }^{2}$ Универзийейска Бизнис Акаяемија во Нови Сая, Фармацевйски Факулиеиеи, 21000 Нови Сая, Србија
}

Клучни зборови: аналгетици, кофеин, храна, HPLC, површински води

Кофеинот е супстанција, без мирис, со горчлив вкус, која природно се среќава во кафето, какаото, и во листовите од чај, а намерно се додава во храната и фармацевтските производи. Исто така, може да се најде и во површинската вода во мали концентрации, каде што често се користи како одличен индикатор за присуство на човечки отпад. Целта на ова истражување е определување на содржината на кофеин во храна, пијалоци, аналгетици и површински води со цврсто-фазна екстракција проследена со течна хроматографија под висок притисок (HPLC). Содржината на кофеин е утврдена во 12 комерцијални производи од чај и кафе, безалкохолни енергетски пијалаци и храна, 5 комбинирани препарати на аналгетици и примероци собрани од реката Дунав од 7 репрезентативни локации на територијата на Нови Сад, Србија. Резултатите покажаа дека содржината на кофеинот се движи од 5,6-158 mg/100 $\mathrm{g}$ во храната, 24,71-30,81 mg/100 ml во примероците од чај, 1328-3594 mg/100 g во примероците од кафе, 9,69-30 $79 \mathrm{mg} / 100 \mathrm{ml}$ во енергетските пијалоци и 15,91-306,12 ng/1 во примероците собрани од реката Дунав. Содржината на кофеин во комбинацијата на комерцијални формулации на не-наркотични аналгетици на сите брендови ги задоволува спецификациите. Податоците сугерираат дека предложениот HPLC метод може да се користи за рутинско определување и контрола на содржината на кофеин во различни матрици. 